\title{
Policresulen, a novel NS2B/NS3 protease inhibitor, effectively inhibits the replication of DENV2 virus in BHK-21 cells
}

\author{
Deng-wei $\mathrm{WU}^{1, \#}$, Fei MAO ${ }^{2, \#}$, Yan $\mathrm{YE}^{3}$, Jian $\mathrm{LI}^{2}$, Chuan-lian $\mathrm{XU}^{1, *}$, Xiao-min $\mathrm{LUO}^{3}$, Jing $\mathrm{CHEN}^{3, *}, \mathrm{Xu} \mathrm{SHEN}^{3}$ \\ ${ }^{1}$ College of Life Sciences, Zhejiang Sci-Tech University, Hangzhou 310018, China; ${ }^{2}$ Shanghai Key Laboratory of New Drug Design, \\ School of Pharmacy, East China University of Science and Technology, Shanghai 200237, China; ${ }^{3}$ CAS Key Laboratory of Receptor \\ Research, Shanghai Institute of Materia Medica, Chinese Academy of Sciences, Shanghai 201203, China
}

Aim: Dengue is a severe epidemic disease caused by dengue virus (DENV) infection, for which no effective treatment is available. The protease complex, consisting of nonstructural protein 3 (NS3) and its cofactor NS2B, plays a pivotal role in the replication of DENV, thus may be a potential target for anti-DENV drugs. Here, we report a novel inhibitor of DENV2 NS2B/NS3 protease and its antiviral action.

Methods: An enzymatic inhibition assay was used for screening DENV2 NS2B/NS3 inhibitors. Cytotoxicity to BHK-21 cells was assessed with MTT assay. Antiviral activity was evaluated in BHK-21 cells transfected with Rlu-DENV-Rep. The molecular mechanisms of the antiviral action was analyzed using surface plasmon resonance, ultraviolet-visible spectral analysis and differential scanning calorimetry assays, as well as molecular docking analysis combined with site-directed mutagenesis.

Results: In our in-house library of old drugs ( 1000 compounds), a topical hemostatic and antiseptic 2-hydroxy-3,5-bis[(4-hydroxy2-methyl-5-sulfophenyl)methyl]-4-methyl-benzene-sulfonic acid (policresulen) was found to be a potent inhibitor of DENV2 NS2B/NS3 protease with $\mathrm{IC}_{50}$ of $0.48 \mu \mathrm{g} / \mathrm{mL}$. Furthermore, policresulen inhibited DENV2 replication in BHK-21 cells with IC ${ }_{50}$ of $4.99 \mu \mathrm{g} / \mathrm{mL}$, whereas its $I \mathrm{I}_{50}$ for cytotoxicity to BHK-21 cells was $459.45 \mu \mathrm{g} / \mathrm{mL}$. Policresulen acted as a competitive inhibitor of the protease, and slightly affected the protease stability. Using biophysical technology-based assays and molecular docking analysis combined with sitedirected mutagenesis, we demonstrated that the residues Gln106 and Arg133 of DENV2 NS2B/NS3 protease directly interacted with policresulen via hydrogen bonding.

Conclusion: Policresulen is a potent inhibitor of DENV2 NS2B/NS3 protease that inhibits DENV2 replication in BHK-21 cells. The binding mode of the protease and policresulen provides useful hints for designing new type of inhibitors against the protease.

Keywords: Dengue virus; antiviral drug; NS2B/NS3 protease; policresulen; molecular docking; molecular modeling

Acta Pharmacologica Sinica (2015) 36: 1126-1136; doi: 10.1038/aps.2015.56; published online 17 Aug 2015

\section{Introduction}

Dengue virus (DENV) belongs to the Flaviviridae family and is primarily spread by mosquitoes. According to a WHO report, approximately 50 to 100 million people in subtropical and tropical regions of the world are infected with DENV annually ${ }^{[1]}$. There are four antigenically distinct viral serotypes for DENV, including DENV1, DENV2, DENV3 and DENV4 ${ }^{[2]}$, among which DENV2 is the most prevalent ${ }^{[3]}$. Infection with any of the four serotypes will result in severe epidemic diseases, such

\footnotetext{
\#The two authors contributed equally to this work.

* To whom correspondence should be addressed.

E-mail jingchen@simm.ac.cn (Jing CHEN); chuanlianxu@163.com (Chuan-lian XU)

Received 2015-02-02 Accepted 2015-05-08
}

as dengue fever (DF), and even fatal diseases, including dengue hemorrhagic fever (DHF) and dengue shock syndrome $(\mathrm{DSS})^{[4,5]}$. The development of an efficient vaccine or antiviral drugs is thus extremely necessary. However, vaccine development against DENV is challenging because of the antibodydependent enhancement effect (ADE) (ie, infection by one serotype of DENV can enhance the probability of infection by any of the other three serotypes) ${ }^{[6]}$, and for more complicated barriers in anti-virus drug discovery ${ }^{[7-9]}$, there are not yet effective antiviral drugs in the market against DENV, although many drug lead compounds have been discovered ${ }^{[10,11]}$.

The DENV genome, a positive-sense single-stranded RNA, encodes a single poly-protein precursor that consists of three structural proteins (C, M, and E) and seven nonstructural 
proteins (NS1, NS2A, NS2B, NS3, NS4A, NS4B, and NS5). Previous studies have shown that NS3 contains two functional domains: a serine protease at the N-terminus and an RNA helicase at the C-terminus ${ }^{[12-14]}$. NS2B is an essential element that acts as a co-factor to greatly enhance the activity of NS3 by 3300 - to $6600-$ fold $^{[15,16]}$. As a viral protease complex, NS2B/ NS3 is mainly in charge of cleaving the viral poly-protein precursor to generate structural proteins and nonstructural proteins, and the disruption of NS2B/NS3 protease function distinctly inhibits viral replication ${ }^{[17]}$. Therefore, the NS2B/ NS3 protease is considered as an attractive target for antiDENV drug development ${ }^{[14]}$. In fact, the treatment of human immunodeficiency virus (HIV) and hepatitis $\mathrm{C}$ virus (HCV) infections serve as successful precedents for targeting key viral proteases $^{[18-20]}$.

Currently, the discovery of a NS2B/NS3 protease inhibitor mainly involves the design of peptidomimetics with similar structures to the substrate of the NS2B/NS3 protease and screening small molecule inhibitors by random or virtual screening strategies against commercial compound libraries. For example, one cyclopentapeptide was proposed as an inhibitor of the DENV2 NS2B/NS3 protease ${ }^{[21]}$, and MrIA, a type of conotoxin, was also determined to be an inhibitor for this protease ${ }^{[22]}$. Recently, varied types of potential inhibitors against the DENV2 NS2B/NS3 protease have been reported ${ }^{[11,23-28]}$, but few inhibitors exhibited antiviral activities. Therefore, it is urgent to discover novel NS2B/NS3 protease inhibitors with high activities against dengue virus.

In the current work, we performed an enzymatic inhibition assay to discover inhibitors of this recombinant DENV2 NS2B/NS3 protease in vitro against our in-house library of old drugs, and 2-hydroxy-3,5-bis[(4-hydroxy-2-methyl-5-sulfophenyl)methyl]-4-methyl-benzenesulfonic acid (policresulen, Figure 1A), a clinical medication used for debridement and antimicrobial applications in gynecology ${ }^{[29]}$, was finally discovered to be a novel inhibitor of this protease. The subsequent discovery of its antiviral properties demonstrated that policresulen could efficiently reduce the replication of DENV2 in BHK-21 cells. Additionally, the molecular mechanism of policresulen against the DENV2 NS2B/NS3 protease was further investigated by binding affinity, thermal stability and molecular docking assays. Our results have demonstrated that policresulen might have potential in the treatment of DENV infection, and the expounded binding pocket of policresulen for this protease may provide useful data for designing new inhibitors against DENV.

\section{Materials and methods Materials}

All reagents were of analytical grade and were obtained commercially. Policresulen was purchased from Anhui Dexinjia Bio-Tech Co (Ji-nan, Shangdong Province, China). Dimethyl sulfoxide (DMSO) and 3-(4,5-dimethylthiazol-2-yl)-2,5-diphenyl tetrazolium bromide (MTT) were purchased from Sigma (St Louis, MO, USA). Yeast extract and tryptone were purchased from Oxoid (Basingstoke Hampshere, England).
Dulbecco's modified Eagle's medium (DMEM) was acquired from Invitrogen (Carlsbad, CA, USA), and fetal bovine serum (FBS) was acquired from Gibco (Grand Island, NY, USA). CM5 chips and resin were purchased from GE healthcare (Piscataway, NJ, USA). Bz-Nle-KRR-AMC was synthesized by Shanghai GL Biochem. The mMESSAGE MEGAscript ${ }^{\circledR}$ T7 Kit was acquired from Ambion (TX, USA). The Renilla Luciferase Assay Kit was acquired from Promega (Madison, WI, USA). The Fast Mutagenesis Kit was acquired from Beijing TransGene Biotech (Beijing).

\section{Cell culture}

Baby Hamster Syrian Kidney (BHK-21) cells were cultured in DMEM containing 10\% FBS, 100 units/mL penicillin and 100 $\mu \mathrm{g} / \mathrm{mL}$ streptomycin at $37^{\circ} \mathrm{C}$ in a humidified $5 \% \mathrm{CO}_{2}$ incubator.

\section{Expression and purification of the DENV2 NS2B/NS3 protease} The pET15b-DENV2 CF40-Gly-NS3pro185 plasmid was donated by Prof Chun-guang WANG (Institute of Protein Research, Tongji University). The plasmid was transformed into Escherichia coli BL21, and DENV2 NS2B/NS3 protease expression and purification were mainly carried out according to the published approach ${ }^{[30]}$. Briefly, Escherichia coli BL21, transformed with the recombinant plasmid, was cultured in $1 \mathrm{~L}$ of Luria-Bertani medium containing $1 \mathrm{mmol} / \mathrm{L}$ ampicillin, $0.5 \mathrm{mmol} / \mathrm{L}$ chloramphenicol and $0.2 \%(w / v)$ glucose at $37^{\circ} \mathrm{C}$, and then induced with $0.1 \mathrm{mmol} / \mathrm{L}$ isopropyl $\beta-D-1$ thiogalactopyranoside (IPTG) until the $O D_{600}$ reached 0.6 after an additional $8 \mathrm{~h}$ at $16^{\circ} \mathrm{C}$. Bacteria were collected by centrifugation at $12000 \times g$ for $5 \mathrm{~min}$ at $4{ }^{\circ} \mathrm{C}$. The harvested bacteria were suspended in $20 \mathrm{~mL}$ of lysis buffer [ $50 \mathrm{mmol} / \mathrm{L}$ HEPES, $300 \mathrm{mmol} / \mathrm{L} \mathrm{NaCl}$, and $5 \%(v / v)$ glycerol, $\mathrm{pH} 7.5]$, lysed by probe sonication on ice, and then centrifuged at $12000 \times g$ for 60 min at $4{ }^{\circ} \mathrm{C}$. The supernatant was mixed with $\mathrm{Ni}^{2+}$-NTA resin in a column and incubated for $8 \mathrm{~h}$ at $4{ }^{\circ} \mathrm{C}$. The column was then extensively washed with $100 \mathrm{~mL}$ of washing buffer $(10 \mathrm{mmol} / \mathrm{L}$ imidazole, $500 \mathrm{mmol} / \mathrm{L} \mathrm{NaCl}$, and $20 \mathrm{mmol} / \mathrm{L}$ Tris, $\mathrm{pH}$ 8.0), and the protein was slowly eluted with $20 \mathrm{~mL}$ of elution buffer $(120 \mathrm{mmol} / \mathrm{L}$ imidazole, $500 \mathrm{mmol} / \mathrm{L} \mathrm{NaCl}$, and $20 \mathrm{mmol} / \mathrm{L}$ Tris, $\mathrm{pH}$ 8.0). To obtain high purity of the protein, the eluted protein was further purified by Superdex $75 \mathrm{Gel}$ Filtration. Finally, the purified protein was concentrated and stored at $-80^{\circ} \mathrm{C}$.

\section{Enzymatic inhibition assay}

The enzymatic inhibition assay was performed in Greiner Black 96-well plates according to the published approach ${ }^{[22]}$. Briefly, $100 \mu \mathrm{L}$ of reaction mixtures containing $50 \mathrm{mmol} / \mathrm{L}$ Tris- $\mathrm{HCl}$ ( $\mathrm{pH} 8.5), 20 \%$ v/v glycerol, $10 \mathrm{mmol} / \mathrm{L} \mathrm{NaCl}, 1$ $\mathrm{mmol} / \mathrm{L}$ CHAPS, $200 \mathrm{nmol} / \mathrm{L}$ NS2B/NS3 protease and the compound dissolved in DMSO were pre-incubated at $37^{\circ} \mathrm{C}$ for $30 \mathrm{~min}$, and the reaction was then started by the addition of the substrate (Bz-Nle-KRR-AMC) to a final concentration of $100 \mu \mathrm{mol} / \mathrm{L}$. Aprotinin $\left(1 \mu \mathrm{mol} / \mathrm{L}^{[31]}\right)$ was used as a positive control. DENV2 NS2B/NS3 protease activity was monitored 
by the increase in fluorescence with a microplate spectrophotometer. The excitation and emission wavelengths were set at 380 and $460 \mathrm{~nm}$, respectively. To determine the 50\% inhibitory concentration $\left(\mathrm{IC}_{50}\right)$ of policresulen, different concentrations of policresulen $(0,0.001,0.01,0.1,0.5,1,10$, and $20 \mu \mathrm{g} / \mathrm{mL})$ were prepared. The $\mathrm{IC}_{50}$ value was calculated using Origin 5, and the inhibitor type was determined using the Lineweaver-Burk plot $^{[32]}$.

\section{Cytotoxicity assay}

The sensitivity of cell lines to policresulen was investigated using an MTT assay. Briefly, BHK-21 cells were seeded into 96-well plates containing $100 \mu \mathrm{L}$ of culture medium at a density of $1 \times 10^{5}$ cells per well and were incubated overnight at $37^{\circ} \mathrm{C}$. Different concentrations of policresulen $(0,50,100,200$, $400,800,1600$, and $3200 \mu \mathrm{g} / \mathrm{mL}$ ) were added and cultured for $48 \mathrm{~h}$. Subsequently, $25 \mu \mathrm{L}$ of MTT $(5 \mathrm{mg} / \mathrm{mL})$ was added and incubated for an additional $4 \mathrm{~h}$. Finally, $125 \mu \mathrm{L}$ of SDS-isobutanol-HCl solution (10\% SDS, 5\% isobutanol, and $12 \mu \mathrm{mol} / \mathrm{L}$ $\mathrm{HCl}$ ) was added to each well and thoroughly mixed for $2 \mathrm{~h}$ to dissolve the formazan crystals. The optical absorption of $570 \mathrm{~nm}$ was measured with a multimode microplate reader (Varioskan, Thermo Scientific, USA). The cell viability in each well was calculated by the following equation: Viability rate $(\%)=\left(A_{570 \mathrm{~nm}}\right.$ of wells that contained the drug $/ A_{570 \mathrm{~nm}}$ of free well $) \times 100 \%{ }^{[33]}$.

\section{Luciferase assay}

The reporter pACYC-DENV2-Rluc2A replicon (Rlu-DENVRep) was used to evaluate the translation and synthesis of DENV2 RNA. RNAs were transcribed from the pACYCDENV2-Rluc2A replicon in vitro using a mMESSAGE MEGAscript ${ }^{\circledR}$ T7 Kit according to the manufacturer's protocols. BHK21 cells transfected with Rlu-DENV-Rep RNAs at MOI=0.1 were seeded into 24 -well plates containing $200 \mu \mathrm{L}$ of culture medium at a density of $5 \times 10^{5}$ cells per well and were incubated for $1 \mathrm{~h}$ at $37^{\circ} \mathrm{C}$. Varied concentrations of policresulen $(0,0.882,1.76,3.53,7.06,14.11$, and $28.22 \mu \mathrm{g} / \mathrm{mL})$ were then added to the medium and incubated for $48 \mathrm{~h}$ at $37^{\circ} \mathrm{C}$. After removing the medium, the cells were washed once with PBS, followed by the addition of $100 \mu \mathrm{L}$ lysis buffer to each well. Fifty microliters of luciferase substrate was then added into the sample wells (20 $\mu \mathrm{L}$ cell lysates), which was assayed for luciferase signal with a multimode microplate reader (Varioskan Flash). The inhibition rate of policresulen was obtained from the following equation: Inhibition rate $(\%)=(1$-luciferase intensity of wells with drug/luciferase intensity of free wells) $\times 100 \%$. IC 50 was calculated using the trimmed Kärber method $^{[34]}$.

\section{Surface plasmon resonance (SPR) technology-based assay}

The binding affinity of policresulen for the DENV2 NS2B/ NS3 protease was investigated using an SPR technology-based Biacore T200 instrument (GE Healthcare). Purified NS2B/NS3 protease was immobilized on CM5 chips in a standard aminecoupling reaction in $10 \mathrm{mmol} / \mathrm{L}$ sodium acetate buffer $(\mathrm{pH}$
4.0 ) at $25^{\circ} \mathrm{C}$. Before immobilization, the chip was equilibrated with HBS-EP buffer [10 mmol/L HEPES, $3 \mathrm{mmol} / \mathrm{L}$ EDTA, $150 \mathrm{mmol} / \mathrm{L} \mathrm{NaCl}$, and $0.005 \%$ ( $/ v$ ) surfactant P20, pH 7.4] for $120 \mathrm{~min}$. Different concentrations $(0.24,0.35,0.49,0.71,1.00$, $1.44,2.06$, and $2.94 \mu \mathrm{g} / \mathrm{mL}$ ) of policresulen dissolved in HBSEP buffer were then injected into the chips with a flow rate of $30 \mu \mathrm{L} / \mathrm{min}$ for $2 \mathrm{~min}$, followed by disassociation for $4 \mathrm{~min}$. The equilibrium dissociation constant $\left(K_{\mathrm{D}}\right)$ of policresulen was calculated using a 1:1 Langmuir binding model based on the Biacore T200 evaluation software.

\section{Ultraviolet-Visible (UV) spectral analysis}

UV spectral analysis was used to investigate the interaction between the DENV2 NS2B/NS3 protease and policresulen. The UV spectrum was monitored using a U-2010 Spectrophotometer. In the assay, a $20 \mu \mathrm{mol} / \mathrm{L}$ NS2B/NS3 sample was prepared in a solution of $50 \mathrm{mmol} / \mathrm{L}$ HEPES ( $\mathrm{pH} 7.5$ ) and 300 $\mathrm{mmol} / \mathrm{L} \mathrm{NaCl}$. The NS2B/NS3 protease was then incubated with policresulen at $25{ }^{\circ} \mathrm{C}$ for $10 \mathrm{~min}$ in the dark. UV spectra were detected in the range of 190-340 $\mathrm{nm}$ at room temperature. Experimental data are the average values of at least three measurements and were corrected by subtracting a blank obtained under the same conditions.

\section{Differential scanning calorimetry (DSC) assay}

The DSC experiment was performed with a VP-Capillary DSC System (GE Healthcare) under a stream of $\mathrm{N}_{2}$. Protein samples were dialyzed against a $50 \mathrm{mmol} / \mathrm{L} \mathrm{HEPES} \mathrm{(} \mathrm{pH} 7.5)$, $300 \mathrm{mmol} / \mathrm{L} \mathrm{NaCl}$ buffer overnight at $4^{\circ} \mathrm{C}$. The test sample consisted of protein alone or protein with policresulen, respectively. The dialysate was used as a reference, and all samples were filtered before use. Two hundred microliter samples were then added into 96-well plates until the plates were loaded into the calorimeter at $10{ }^{\circ} \mathrm{C}$. The scan temperature ranged from 10 to $110{ }^{\circ} \mathrm{C}$ with a heating rate of $1.5{ }^{\circ} \mathrm{C} / \mathrm{min}$. The mid-feedback mode was selected, and the $\mathrm{Cp}$ value was read every $3 \mathrm{~s}$. The thermal transition midpoints (Tm) of samples were analyzed using Origin 5.0 software.

\section{Molecular docking}

The molecular docking of the inhibitor policresulen in the substrate binding pocket of the DENV2 NS2B/NS3 protease was performed using the Schrödinger program Maestro (Version 9.2) according to the previously published protocol ${ }^{[35-37]}$ using the structure of NS2B/NS3 protease in PDB ID 2M9Q as the model. For docking, the structure of the protein was prepared by Protein Preparation Wizard and the inhibitor by Ligprep $^{[38,39]}$. Gulie was used to study the binding conformation between the protein and inhibitor.

\section{Site-directed mutagenesis of the NS2B/NS3 protease}

Mutant plasmids for DENV2 NS2B/NS3 (NS2B/NS3-Q106G, NS2B/NS3-R133G, and NS2B/NS3-Q106G/R133G) were generated using the Fast Mutagenesis Kit (TransGene Biotech, Beijing, China). Site-directed mutagenesis of the residues was performed on pET15b-DENV2CF40-Gly-NS3pro185 accord- 
Table 1. The primers of DENV2 NS2B/NS3 mutant gene.

\begin{tabular}{ll}
\hline Primers & Sequence (5'-3') \\
\hline Q106G-Sence & ATGGAGCCTATAGAATCAAGGGGAAAGGGATTC \\
Q106G-AntiSence & CCCTTGATTCTATAGGCTCCATCTTCCAGTTCG \\
R133G-Sence & ACAATGTGGCACGTCACAGGAGGTGCTGTCCT \\
R133G-AntiSence & TCCTGTGACGTGCCACATTGTGTGGAATGTTCC \\
\hline
\end{tabular}

ing to a modified recombinant PCR method ${ }^{[40]}$. The oligonucleotide sequences of the primers used to generate DENV2 NS2B/NS3 mutant genes are listed in Table 1. All mutants were confirmed by DNA sequencing. Escherichia coli BL21 was transformed with mutant genes and used for the expression of mutant proteins. The method for the expression and purification of the mutant proteins was similar to that used for the wild-type protein.

\section{Results}

Policresulen is an inhibitor of the DENV2 NS2B/NS3 protease

To discover DENV2 NS2B/NS3 protease inhibitors, we performed a screening assay based on an enzymatic test against our in-house library of old drugs ( 1000 compounds), and the agent 2-hydroxy-3,5-bis[(4-hydroxy-2-methyl-5-sulfophenyl)methyl]-4-methyl-benzenesulfonic acid (policresulen, Figure 1A) was finally identified as a potent inhibitor of the protease, with an $\mathrm{IC}_{50}$ of $0.48 \mu \mathrm{g} / \mathrm{mL}$ (Figure 1B).

To exclude the possibility of interference from policresulen on the substrate or on DENV2 NS2B/NS3 protease in the enzymatic inhibition assay, the following experiments were conducted. First, a similar enzymatic inhibition assay without the NS2B/NS3 protease was performed to detect the effect of policresulen on the substrate. As shown in Figure S1, the presence of policresulen did not influence the fluorescence of the substrate. Second, to exclude the possibility of policresuleninhibited DENV2 NS2B/NS3 protease enzymatic activity due to the weak acidity of the compound, circular dichroism (CD) was carried out. As indicated in Figure S2, policresulen rendered no effects on the structure of the NS2B/NS3 protease, even at $20 \mu \mathrm{g} / \mathrm{mL}$, which was the maximum concentration used in the enzymatic inhibition assay.

In addition, the MTT assay results demonstrated a very low cytotoxicity for policresulen in BHK-21 cells, as indicated by the fact that more than $50 \%$ of BHK-21 cells remained viable, even though policresulen reached concentrations as high as $459.45 \mu \mathrm{g} / \mathrm{mL}$ (Figure 1C). Moreover, this result also confirmed that the weakly acidic property of policresulen had no effect on the tested cells, which is consistent with the CD spectral results (Figure S2).

Because policresulen is a mixture of several analog compounds ${ }^{[41]}$, electrospray ionization mass spectrometry (ESIMS) was performed for the policresulen used in our work to characterize the precise molecular weight of every component. The pseudo molecular ion peak (negative ion mode) profiles of policresulen are shown in Figure S3. Two ion peaks (387.1 and
A<smiles>Cc1cc(O)c(S(=O)(=O)O)cc1CCc1cc(S(=O)(=O)O)c(C)c(CCc2c(C)c(S(=O)(=O)O)cc(O)c2O)c1C</smiles>

Policresulen

B

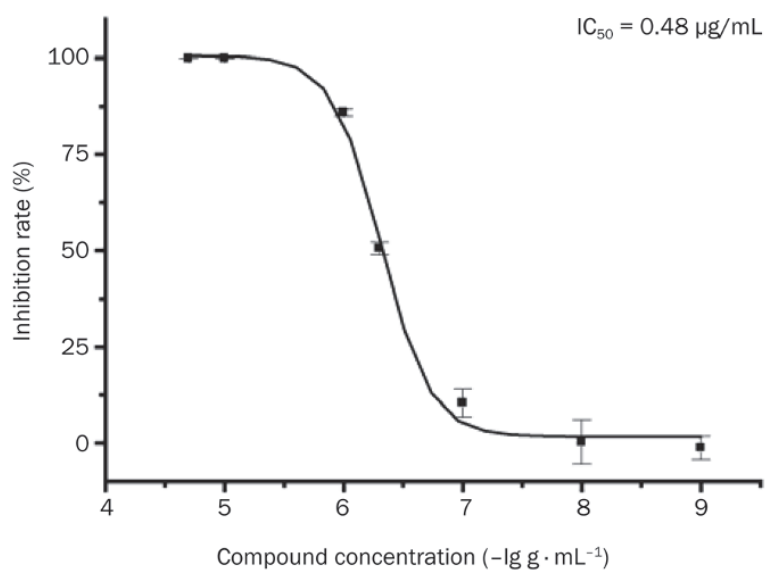

C

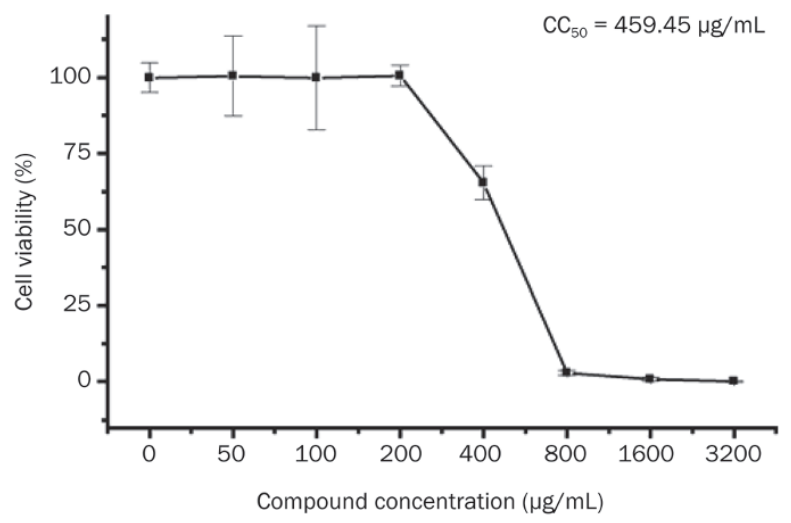

Figure 1. Policresulen functioned as an inhibitor of DENV2 NS2B/NS3 protease. (A) Chemical structure of policresulen. (B) The dose-dependent inhibitory effect of policresulen against DENV2 NS2B/NS3 protease. (C) The cytotoxicity of policresulen was evaluated by MTT assay. BHK-21 cells were treated with different concentrations of policresulen for $48 \mathrm{~h}$.

774.7) with the highest relative abundances represent component $\mathrm{B}$ and its dimer, respectively. In addition, there was an obvious ion peak (587.0) that represents component C, which suggests that there are three components of the policresulen used in our work.

Taken together, these results indicated that policresulen is an efficient inhibitor of DENV2 NS2B/NS3 protease with low cytotoxicity in BHK-21 cells.

Policresulen inhibited the replication of DENV2

Given that policresulen has been determined to inhibit the 
A

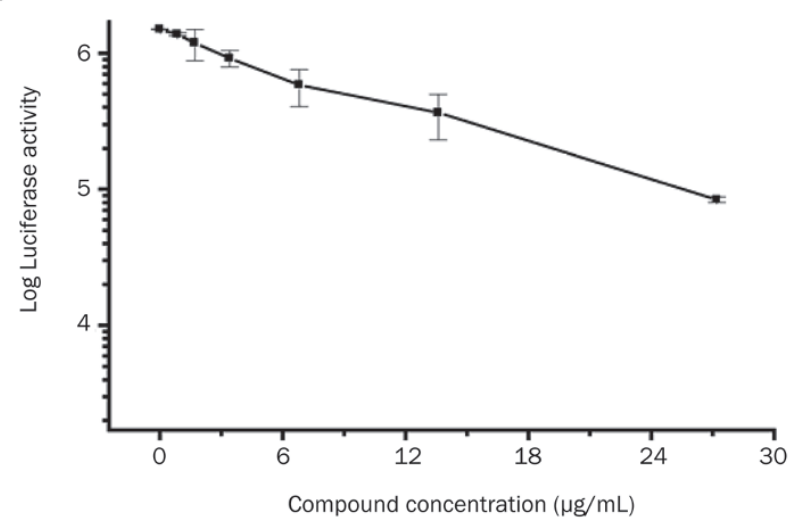

B

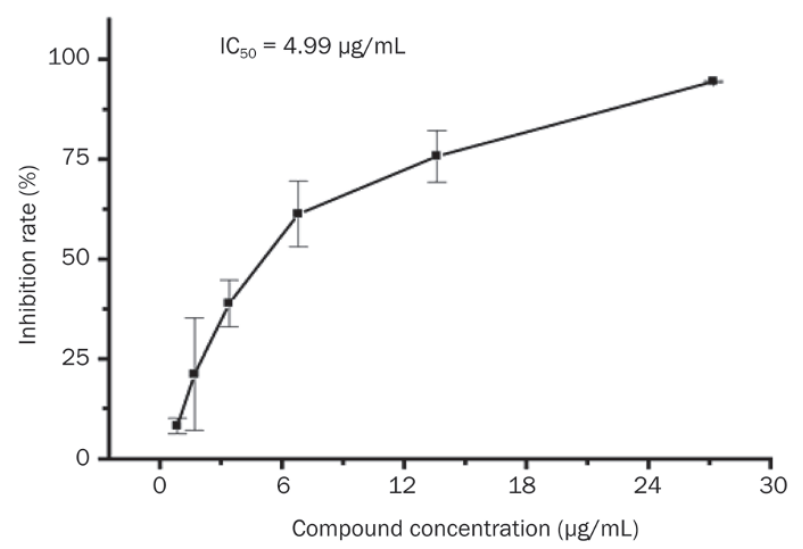

Figure 2. Policresulen efficiently inhibited the replication of DENV2. (A) BHK-21 cells transfected with Rlu-DENV-Rep were treated with different concentrations of policresulen for $48 \mathrm{~h}$. The cells were harvested, and luciferase activities were measured using Renilia Luciferase Assay Kit. (B) The inhibitory rate of policresulen at different concentrations against DENV2 replicon was converted from luciferase activity.

DENV2 NS2B/NS3 protease, we next evaluated its potential antiviral activity against DENV2 on the cellular level. RlucDENV2-Rep which includes a reporter gene (Renilla luciferase, Rluc) and the full genome of DENV2 (pACYC-DENV2-Rluc2A replicon) were used to examine the antiviral effects of policresulen $^{[42]}$. In this assay, DENV2 RNA, which included an Rluc gene transcribed from Rluc-DENV2-Rep, was transfected into BHK-21 cells, and the ability of the virus to replicate was monitored by detecting the activity of Renilla luciferase at $48 \mathrm{~h}$ post-infection. As indicated in Figure 2A and B, policresulen could effectively inhibit the luciferase activity in a dosedependent manner, with an $\mathrm{IC}_{50}$ of $4.99 \mu \mathrm{g} / \mathrm{mL}$. This result, combined with that from the cytotoxicity assay, shows a high therapeutic index (TI) for policresulen of 92.07 .

\section{Policresulen acted as a competitive inhibitor of the DENV2} NS2B/NS3 protease

Inhibitor type assay Because policresulen has been determined to be a DENV2 NS2B/NS3 protease inhibitor able to efficiently suppress the replication of DENV2, we next investigated the
A

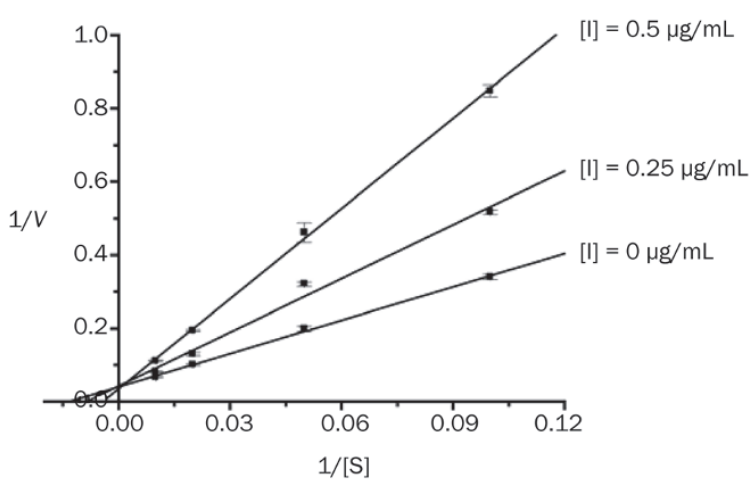

B

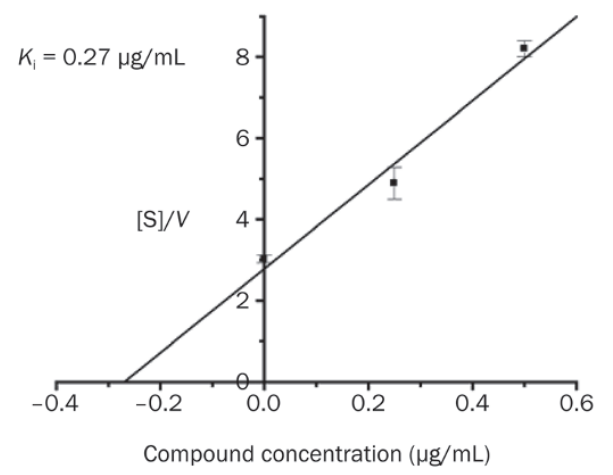

C

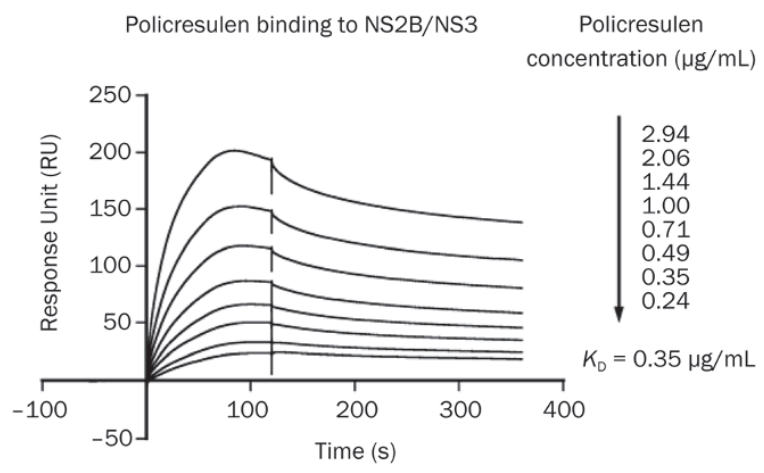

Figure 3. Policresulen as a competitive inhibitor exhibited binding affinity to DENV2 NS2B/NS3 protease. (A) Kinetic analysis of policresulen against NS2B/NS3 protease via double reciprocal plots of $1 / \mathrm{V}$ versus $1 /[\mathrm{S}]$. (B) Secondary plot of [S]/ $V$ versus different concentrations of policresulen. The inhibitory constant value was then determined using linear regression analysis. (C) Binding ability of policresulen to DENV2 NS2B/NS3 protease. The $K_{D}$ value of policresulen to NS2B/NS3 protease was fitted with 1:1 Langmuir binding model by BiacoreT200 evaluation software. $R_{\max }$ for policresulen binding to NS2B/NS3 protease was $257.8 \mathrm{Ru}$.

manner in which it inhibits the DENV2 NS2B/NS3 protease. As shown in Figure 3A, the Lineweaver-Burk plot analysis from the enzymatic inhibition data indicates that policresulen acted as a competitive inhibitor against the DENV2 NS2B/ NS3 protease with an inhibitory constant $\left(K_{\mathrm{i}}\right)$ value of 0.27 $\mu \mathrm{g} / \mathrm{mL}$ (Figure 3B). 
Surface plasmon resonance (SPR) technology-based assay Next, the binding affinity of policresulen against the DENV2 NS2B/ NS3 protease was detected using an SPR technology-based Biacore assay, in which the interaction between policresulen and the immobilized protease is reported as a sensorgram, which is a plot of the binding response represented by response unit (RU) versus time. From the SPR assay sensorgrams, slow off-rate binding kinetics were observed between policresulen and the NS2B/NS3 protease in the binding model, and the same results were also discovered in other small molecule-protein interactions ${ }^{[43]}$. Additionally, the gradual increases in RU values as compared to the changes in policresulen concentrations demonstrated specific binding of policresulen to the NS2B/NS3 protease. The dissociation equilibrium constant $\left(K_{\mathrm{D}}\right)$ value of policresulen from the protease was thereby fitted to $0.35 \mu \mathrm{g} / \mathrm{mL}$ (Figure 3C), and the $R_{\max }$ value for policresulen binding to NS2B/NS3 protease was 257.8 Ru. Therefore, policresulen was determined to be a competitive inhibitor able to bind directly to the DENV2 NS2B/ NS3 protease.

\section{Policresulen reduced the stability of the DENV2 NS2B/NS3 protease}

To further elucidate the molecular mechanism used by policresulen in the inhibition of the DENV2 NS2B/NS3 protease, ultraviolet-visible (UV) spectral analysis and differential scanning calorimetry (DSC) assays were carried out.

UV spectral analysis It is well-known that proteins have two strong absorption peaks of $\sim 190-250 \mathrm{~nm}$ and $\sim 280 \mathrm{~nm}^{[44,45]}$. Here, there are two strong absorption peaks at 232 and 278 $\mathrm{nm}$ in the UV spectra of the DENV2 NS2B/NS3 protease. As shown in Figure 4A, the incubation of policresulen with the protease caused a red shift of $7 \mathrm{~nm}$ for the peak at $232 \mathrm{~nm}$ and a decrease in the absorbance intensity, while no changes were observed for the absorption peak at $278 \mathrm{~nm}$. These results implied an interaction of policresulen with the DENV2 NS2B/ NS3 protease, which is consistent with the result of the SPR assay. The red shift of the absorption peak at $232 \mathrm{~nm}$ demonstrated the changed microenvironment of the peptide bond in the DENV2 NS2B/NS3 protease in the presence of policresu$\operatorname{len}^{[46,47]}$.

DSC assay Considering that the result of the UV spectral analysis has revealed that policresulen binding induced changes in the peptide bond microenvironment of the protease, a DSC assay was then applied to investigate the stability of the protease. In this assay, the thermal transition midpoint (Tm), which is related to changes in the conformation of the protein, was detected. As shown in Figure 4B, the Tm value for the DENV2 NS2B/NS3 protease alone was $51.5^{\circ} \mathrm{C}$, and an incubation of policresulen with the protease caused a slight decrease in the $\mathrm{Tm}$ value of the protease to $51.17{ }^{\circ} \mathrm{C}$. This result thus implies that policresulen binding to the DENV2 NS2B/NS3 protease reduced the thermal stability of the protein, but this change was not significant.
A

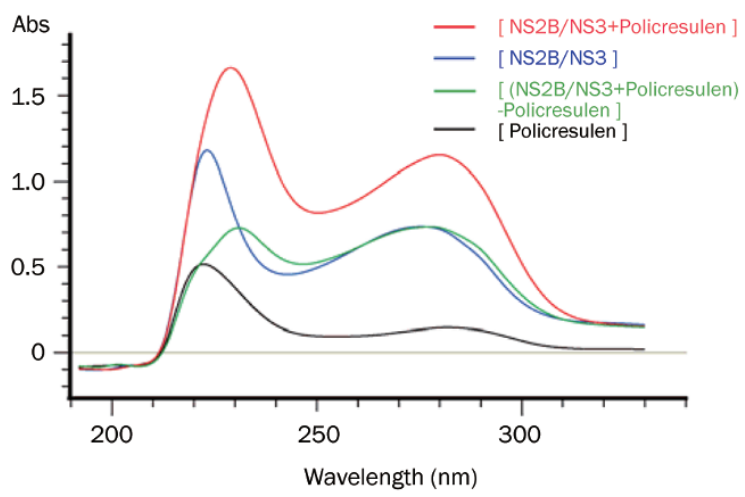

B

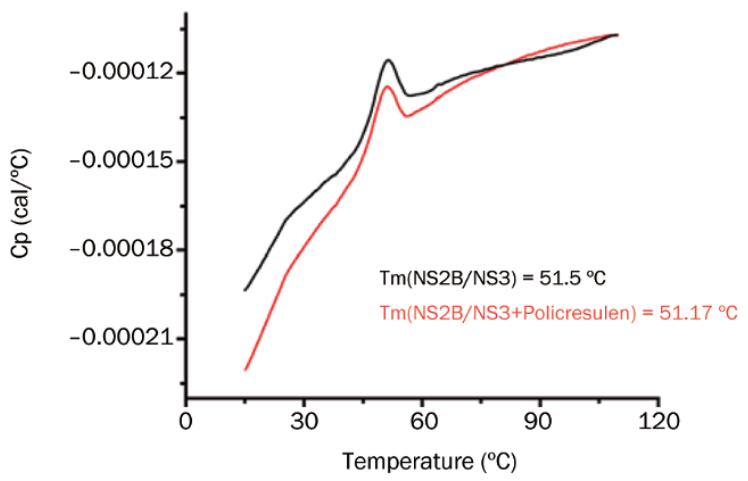

Figure 4. Policresulen reduced the stability of DENV2 NS2B/NS3 protease. (A) UV spectra of NS2B/NS3 protease $(20 \mu \mathrm{mol} / \mathrm{L})$ in presence or absence of policresulen $(23.52 \mu \mathrm{g} / \mathrm{mL})$. Blue curve: absorbance spectrum of NS2B/NS3 protease. Red curve: absorbance spectrum of the protease with policresulen. Green curve: absorbance spectrum of the protease with policresulen (subtracting the effect of policresulen). Black curve: absorbance spectrum of policresulen. (B) The thermal stability of NS2B/NS3 protease combined with or without policresulen was evaluated by DSC thermograms. The temperature of the peak of thermo curve represented the thermal transition midpoints $(\mathrm{Tm})$. Tm value of the protease (black curve) was $51.5^{\circ} \mathrm{C}$, and $\mathrm{Tm}$ value of the protease with policresulen (red curve) was $51.17^{\circ} \mathrm{C}$.

\section{Structural analysis of the DENV2 NS2B/NS3 protease in a complex with policresulen}

Molecular modeling To better understand the method of policresulen binding to the NS2B/NS3 protease, a 3D binding model of policresulen in the substrate binding site of the protease was investigated by molecular docking. For docking analysis, a protein structural model was prepared using the representative conformer of the NMR structure of the DENV2 NS2B/ NS3 protease (PDB ID: 2M9Q), and all amino acid numberings (Figure 5) were based on the sequence of recombinant DENV2 NS2B/NS3 protease. Given that the compound with the structure in Figure 6A is suggested to be one of the major active components of policresulen (PubChem CID: 3050404) ${ }^{[48]}$, this structure for policresulen was thus used for docking analysis. As illustrated in Figure 6B-D, on the left side of policresulen, the oxygen of the sulfo group formed a hydrogen bond with the Gln106 side chain in the P1 region of the protease, and 


\section{G S S H H H H H S G L V P R G S M L E A D L E L E R}

\section{A A D V R W E E Q A E I S G S S P I L S I T I S E D G S M S}

75

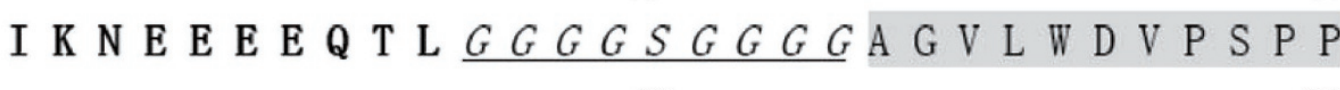

105

P V GKA E L E D G A Y R I K Q K G I L G Y S Q I G A G V Y

$135 \triangle$

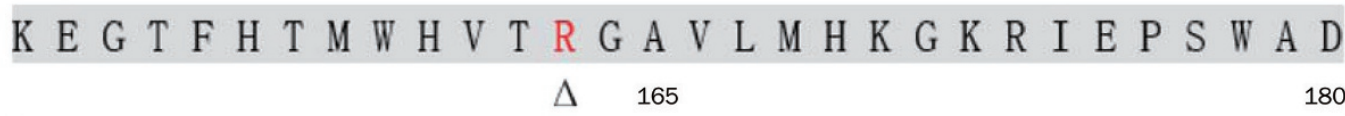

VKK D L I S Y G G GWK L E GE W K E GE E V Q V L A L E

195

Figure 5. Amino acid sequence in DENV2 NS2B/NS3 protease. The residues marked in bold are part of NS2B amino acid sequence. The residues marked in underline are His-tag. The residues 71-79 marked in underline and italics are the $\mathrm{G}_{4}-\mathrm{S}-\mathrm{G}_{4}$ flexible linker in recombinant DENV2 NS2B/NS3 protease. The amino acids of NS3 sequence are highlighted in gray. The locations of the amino acid mutations to generate the variants are indicated by rectangle and the substitute residues are also shown in the rectangle.

the phenol group formed a hydrogen bond with the carbonyl group of the main chain of Gln114. In the middle section of policresulen, the benzene moiety formed hydrophobic interactions with residues Ile109, Ile115, and Val131 in the hydrophobic P2 region of the protease, and the sulfo-group may exhibit electrostatic interactions with His130. On the right side of policresulen, the oxygen of the sulfo-group formed hydrogen bonds with the side chains of residues Thr132 and Arg133 in the positive $\mathrm{P} 3$ region of the protease.

In all, policresulen interacted with residues Gln106, Gln114, Thr132 and Arg133 of the DENV2 NS2B/NS3 protease through hydrogen bonding and residues Ile109, Ile115, Val131 through hydrophobic bonding.

Mutation analysis based validation To validate the binding model of policresulen to the protease that was suggested by the docking results, two typical residues in the binding site of the protease for policresulen, Gln106 and Arg133 (Figure 5 and 6), were chosen for investigation. Single or double sitedirected mutagenesis of the protease (Q106G, R133G, and Q106G/R133G) was thereby carried out.

The mutants Q106G, R133G and Q106G/R133G were expressed and purified using an approach similar to that used for the wild-type protein, and enzymatic assays indicated that mutagenesis of either of these two residues exhibited no effects on the enzymatic activity of the protease (Figure S4). As shown in Figure 7A-C, mutation of either of these two residues caused a large decrease in the inhibitory activity of policresulen against the protease, as is indicated by the increases in the $\mathrm{IC}_{50}$ values for the mutants $\left(\mathrm{IC}_{50}\right.$ : Q106G, 4.99 $\mu \mathrm{g} / \mathrm{mL}$; R133G, $4.3 \mu \mathrm{g} / \mathrm{mL}$; and Q106G/R133G, $60.8 \mu \mathrm{g} / \mathrm{mL}$ ). Notably, the double site-directed mutagenesis (Q106G/ R133G) rendered the greatest influence on the inhibition of the protease by policresulen, given that it had the largest $\mathrm{IC}_{50}$ value among the three mutants. These results all demonstrate that residues Gln106 and Arg133 are responsible for policresulen inhibition of the DENV2 NS2B/NS3 protease.

In addition, to further confirm that the decreased inhibitory activity of policresulen against the mutants was due to the disruption of its binding affinity for the mutants, an SPR-based Biacore assay was carried out. In this test, the purified mutant proteases were immobilized on CM5 chips with 4500-5000 response units (RU), which is similar to the related assays for the wild-type DENV2 NS2B/NS3 protease. As expected, the binding affinity of policresulen for any of the three mutants (Q106G, R133G, Q106G/R133G) was significantly reduced compared to that of the wild-type protease (Figure 7D-F), and the double site-directed mutant Q106G/R133G exhibited the weakest binding affinity for policresulen compared with the 
A<smiles>Cc1cc(O)c(S(=O)(=O)O)cc1Cc1cc(S(=O)(=O)O)c(O)c(Cc2cc(O)c(O)cc2C)c1C</smiles>

C

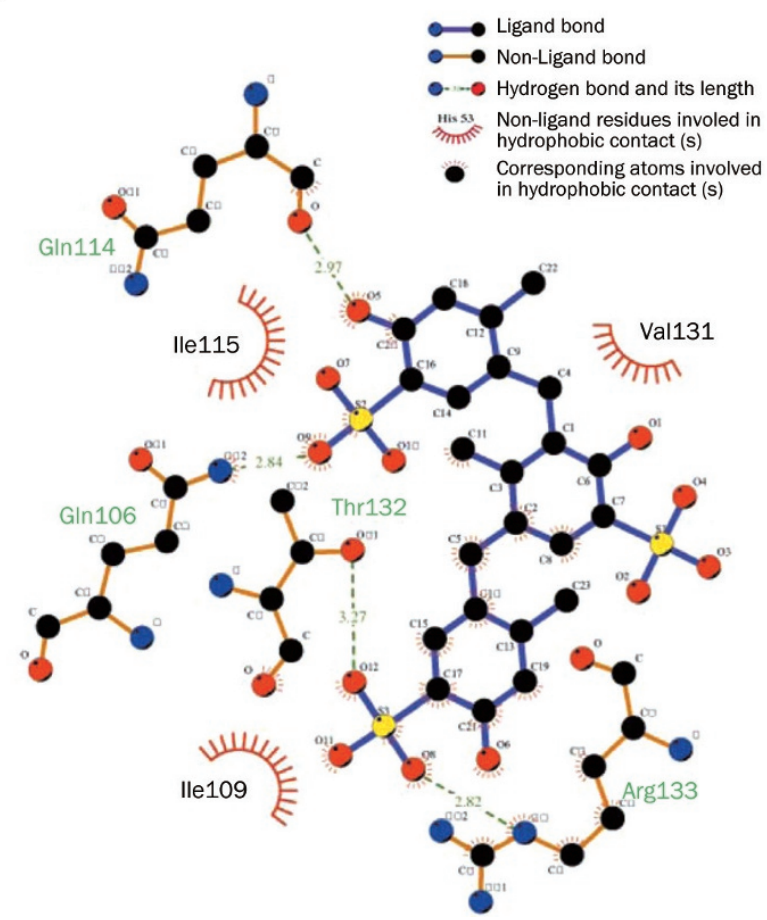

B

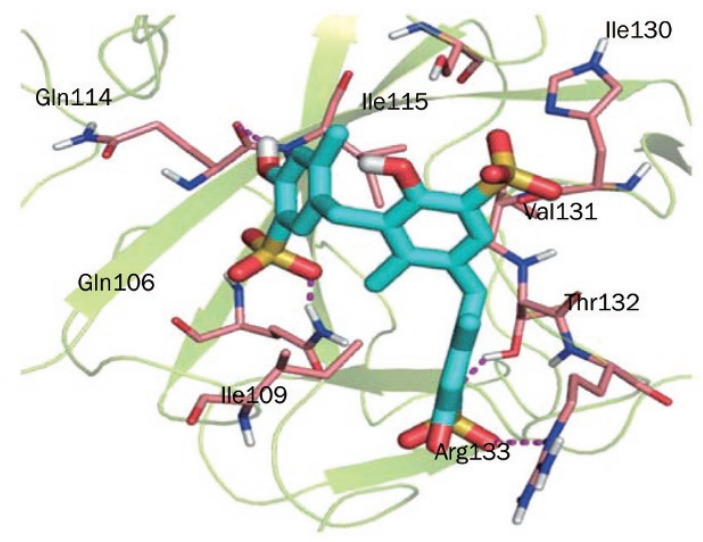

D

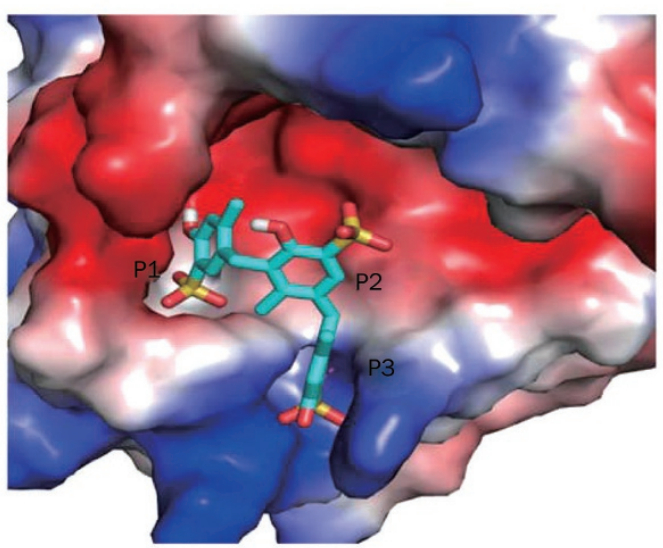

Figure 6. Putative binding mode of policresulen interacting with DENV2 NS2B/NS3 protease. (A) Structure of the major active constituent of policresulen. (B) Binding pose of policresulen at the substrate binding site of DENV2 NS2B/NS3 protease. Hydrogen bonds were shown as pink dotted lines. The poses were prepared using PyMol (http://pymol.sourceforge.net/). (C) Ligplots showed the hydrogen-bond and hydrophobic interactions between policresulen and DENV2 NS2B/NS3 protease. (D) The DENV2 NS2B/NS3 protease surface was colored according to electrostatic potential. The binding subareas were labeled as P1, P2 and P3.

Q106G and R133G mutants. These results thus further confirmed that the Gln106 and Arg133 residues are responsible for policresulen binding to the DENV2 NS2B/NS3 protease.

Therefore, all aforementioned mutation analyses verify that the $\mathrm{G} \ln 106$ and Arg133 residues are important for the binding of policresulen to the DENV2 NS2B/NS3 protease and the inhibition of protease activity, and they further support the docking model of the protease in a complex with policresulen.

\section{Discussion}

To date, several DENV proteases have been identified as potential targets for the discovery of anti-DENV inhibitors, including NS2B/NS3, NS4B and NS5 ${ }^{[49-51]}$, and the NS2B/NS3 protease is particularly important because of its essential role in the replication of $\mathrm{DENV}^{[52]}$. In fact, an inhibition strategy involving the protease complex and facilitated by a co-factor enzyme has been successfully applied in the discovery of antiviral drugs against human immunodeficiency virus (HIV) and hepatitis $\mathrm{C}$ virus $(\mathrm{HCV})^{[53]}$, and several inhibitors targeting the HCV NS3/4A protease have already entered into clinical trials $^{[54-56]}$.

Recently, varied types of potential inhibitors against the DENV2 NS2B/NS3 protease have been discovered ${ }^{[11,23-25,31,57-59]}$ and have provided important structural information for antiDENV drug development. In our current work, given a strategy for new drug discovery that is based on using old drugs to quickly achieve data for preclinical and early clinical trials and thus possibly accelerate new drug development speed ${ }^{[60]}$, we constructed a platform in the discovery of DENV2 NS2B/ NS3 protease inhibitors by targeting an in-house library of old 
A

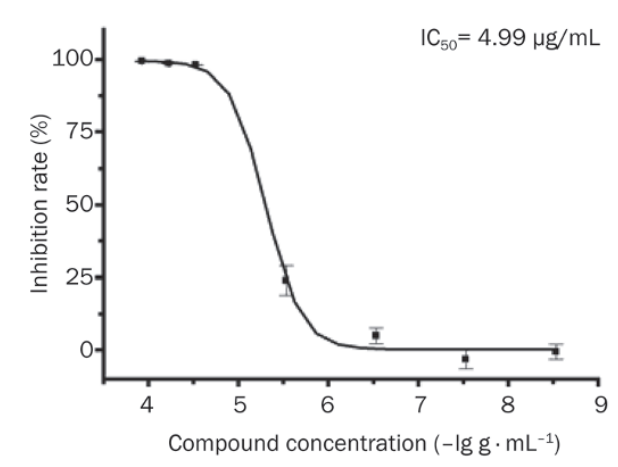

B

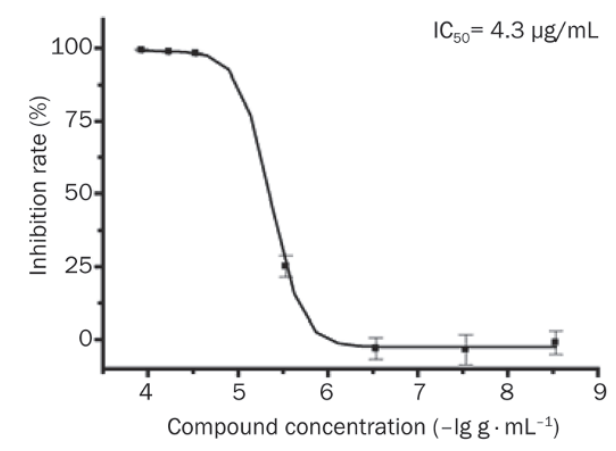

C

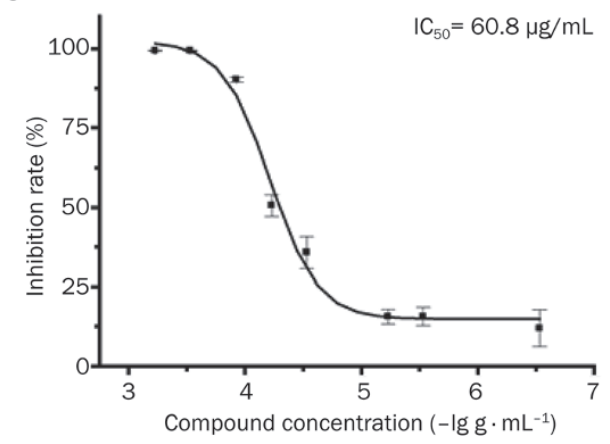

D

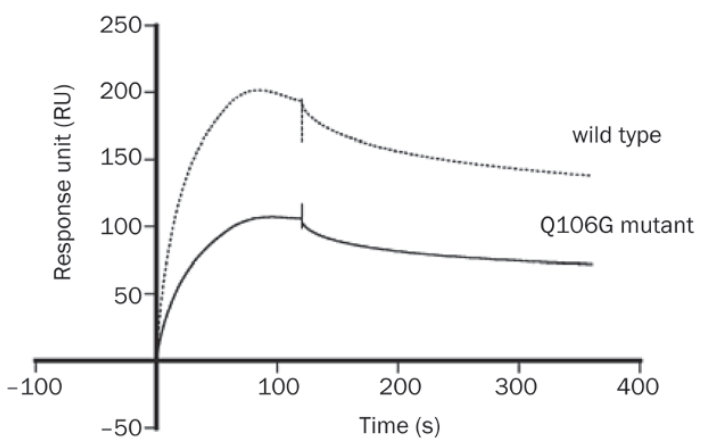

$\mathrm{E}$

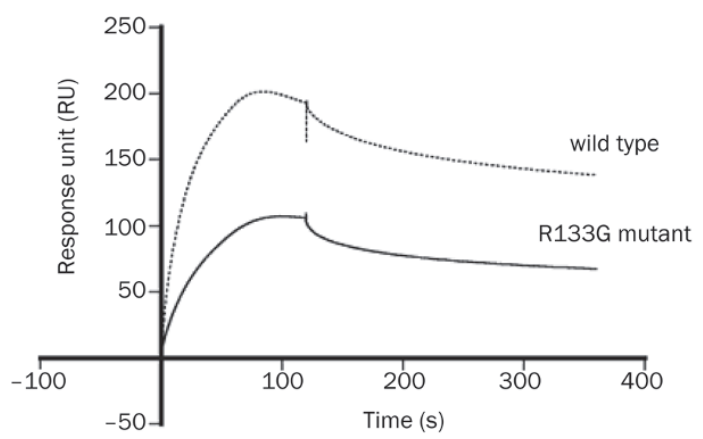

$\mathrm{F}$

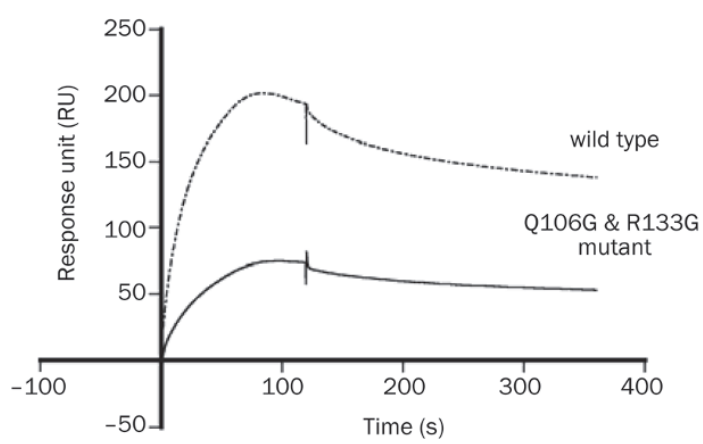

Figure 7. Mutation analysis verified the binding sites of policresulen against DENV2NS2B/NS3 protease. (A-C) IC $_{50}$ of policresulen against NS2B/N33 (Q106G), NS2B/NS3 (R133G) and NS2B/NS3 (Q106G/R133G) were determined as (A) $4.99 \mu \mathrm{g} / \mathrm{mL}$; (B) $4.3 \mu \mathrm{g} / \mathrm{mL}$; (C) $60.8 \mu \mathrm{g} / \mathrm{mL}$, respectively. (DF) Biacore sensorgrams were obtained from injections of policresulen at $2.94 \mu \mathrm{g} / \mathrm{mL}$ over the immobilized. (D) NS2B/N33 (Q106G). (E) NS2B/NS3 (R133G) or (F) NS2B/NS3 (Q106G/R133G). The sensorgram of policresulen at $2.94 \mathrm{\mu g} / \mathrm{mL}$ binding to wild type NS2B/NS3 was shown in dashed line as a control.

drugs. The results demonstrated that policresulen functioned as a novel inhibitor of the DENV2 NS2B/NS3 protease and efficiently suppressed the replication of the DENV2 virus with a high therapeutic index, which has greatly supported the availability and efficiency of this drug discovery platform. It is expected that this platform may also expand its application in discovering effective inhibitors against other viruses, and policresulen may have potential as a drug lead compound for the treatment of DENV.

In addition, the details of policresulen binding to the
DENV2 NS2B/NS3 protease have been illuminated by a series of biophysical technology-based assays and molecular docking analysis combined with site-directed mutagenesis. Residues Gln106 and Arg133 of the protease directly interacted with policresulen via hydrogen bonding, which is an interaction that is very different from that used by the previously reported inhibitors, which bind to the catalytic triad residues (His51, Asp75, and Ser135) of the protease ${ }^{[57,61]}$. Therefore, this newly determined binding arrangement between policresulen and the protease is expected to provide useful hints for designing 
new types of anti-DENV2 NS2B/NS3 protease inhibitors.

Notably, policresulen is an organic acid with hemostatic and antimicrobial activities, and it is used as a clinical medication in gynecology for the treatment of vaginitis ${ }^{[29]}$. Here, we found that policresulen could also function as a DENV2 NS2B/ NS3 inhibitor able to effectively suppress the replication of the DENV2 virus, and this finding has extended the potential pharmacological applications of this agent.

In summary, we discovered that policresulen, when used as a novel DENV2 NS2B/NS3 protease inhibitor, exhibited potent antiviral activity. The determined binding conformation of policresulen and the protease may provide useful hints for designing new types of effective inhibitors against DENV, and policresulen may be used as a potential antiviral drug lead compound against DENV.

\section{Acknowledgements}

We gratefully acknowledge financial support from the National Natural Science Foundation of China (Grant No $81220108025,21222211,81373461,91413102,81473141$, and 91213306).

\section{Author contribution}

Xu SHEN, Jian LI, Chuan-lian XU, Xiao-min LUO and Jing CHEN designed the research; Deng-wei WU, Fei MAO and Yan YE performed the experiments; Xu SHEN and Jing CHEN supervised the project; $\mathrm{Xu}$ SHEN, Jing CHEN, and Deng-wei WU contributed to the manuscript writing. All authors read and approved the final manuscript.

\section{Supplementary Information}

Supplementary figures are available on the website of Acta Pharmacologica Sinica.

\section{References}

1 Guzman MG, Halstead SB, Artsob H, Buchy P, Farrar J, Gubler DJ, et al. Dengue: a continuing global threat. Nat Rev Microbiol 2010; 8 (12 Suppl): 7-16.

2 Bennett SN, Holmes EC, Chirivella M, Rodriguez DM, Beltran M, Vorndam V, et al. Molecular evolution of dengue 2 virus in Puerto Rico: positive selection in the viral envelope accompanies clade reintroduction. J Gen Virol 2006; 87: 885-93.

3 Zuo Z, Liew OW, Chen G, Chong PC, Lee SH, Chen K, et al. Mechanism of NS2B-mediated activation of NS3pro in dengue virus: molecular dynamics simulations and bioassays. J Virol 2009; 83: 1060-70.

4 Rigau-Perez JG, Clark GG, Gubler DJ, Reiter P, Sanders EJ, Vorndam AV. Dengue and dengue haemorrhagic fever. Lancet 1998; 352: 971-7.

5 Murgue B. Severe dengue: questioning the paradigm. Microbes Infect 2010; 12: 113-8.

6 Goncalvez AP, Engle RE, St Claire M, Purcell RH, Lai CJ. Monoclonal antibody-mediated enhancement of dengue virus infection in vitro and in vivo and strategies for prevention. Proc Natl Acad Sci U S A 2007; 104: 9422-7.

7 Yin Z, Patel SJ, Wang WL, Chan WL, Ranga Rao KR, Wang G, et al. Peptide inhibitors of dengue virus NS3 protease. Part 2: SAR study of tetrapeptide aldehyde inhibitors. Bioorg Med Chem Lett 2006; 16 : 40-3.

8 Yin Z, Patel SJ, Wang WL, Wang G, Chan WL, Rao KR, et al. Peptide inhibitors of Dengue virus NS3 protease. Part 1: Warhead. Bioorg Med Chem Lett 2006; 16: 36-9.

9 Shiryaev SA, Ratnikov BI, Chekanov AV, Sikora S, Rozanov DV, Godzik $A$, et al. Cleavage targets and the D-arginine-based inhibitors of the West Nile virus NS3 processing proteinase. Biochem J 2006; 393: 503-11.

10 Noble CG, Chen YL, Dong H, Gu F, Lim SP, Schul W, et al. Strategies for development of Dengue virus inhibitors. Antiviral Res 2010; 85: 450-62.

11 Yang CC, Hsieh YC, Lee SJ, Wu SH, Liao CL, Tsao CH, et al. Novel dengue virus-specific NS2B/NS3 protease inhibitor, BP2109, discovered by a high-throughput screening assay. Antimicrob Agents Chemother 2011; 55: 229-38.

12 Gorbalenya AE, Donchenko AP, Koonin EV, Blinov VM. N-Terminal domains of putative helicases of flaviviruses and pestiviruses may be serine proteases. Nucleic Acids Res 1989; 17: 3889-97.

13 Bazan JF, Fletterick RJ. Detection of a trypsin-like serine protease domain in flaviviruses and pestiviruses. Virology 1989; 171: 637-9.

14 Tomlinson SM, Malmstrom RD, Watowich SJ. New approaches to structure-based discovery of dengue protease inhibitors. Infect Disorders Drug Targets 2009; 9: 327-43.

15 Yusof R, Clum S, Wetzel M, Murthy HM, Padmanabhan R. Purified NS2B/NS3 serine protease of dengue virus type 2 exhibits cofactor NS2B dependence for cleavage of substrates with dibasic amino acids in vitro. J Biol Chem 2000; 275: 9963-9.

16 Falgout B, Pethel M, Zhang YM, Lai CJ. Both nonstructural proteins NS2B and NS3 are required for the proteolytic processing of Dengue virus nonstructural proteins. J Virol 1991; 65: 2467-75.

17 Geiss BJ, Stahla H, Hannah AM, Gari HH, Keenan SM. Focus on flaviviruses: current and future drug targets. Future Med Chem 2009; 1: $327-44$.

18 Lescar J, Luo D, Xu T, Sampath A, Lim SP, Canard B, et al. Towards the design of antiviral inhibitors against flaviviruses: the case for the multifunctional NS3 protein from Dengue virus as a target. Antiviral Res 2008; 80: 94-101.

19 Lin YL, Liao CL, Chen LK, Yeh CT, Liu Cl, Ma SH, et al. Study of Dengue virus infection in SCID mice engrafted with human K562 cells. J Virol 1998; 72: 9729-37.

20 Sampath A, Padmanabhan R. Molecular targets for flavivirus drug discovery. Antiviral Res 2009; 81: 6-15.

21 Tambunan US, Alamudi S. Designing cyclic peptide inhibitor of dengue virus NS3-NS2B protease by using molecular docking approach. Bioinformation 2010; 5: 250-4.

22 Xu S, Li H, Shao X, Fan C, Ericksen B, Liu J, et al. Critical effect of peptide cyclization on the potency of peptide inhibitors against Dengue virus NS2B-NS3 protease. J Med Chem 2012; 55: 6881-7.

23 Pambudi S, Kawashita N, Phanthanawiboon S, Omokoko MD, Masrinoul $\mathrm{P}$, Yamashita A, et al. A small compound targeting the interaction between nonstructural proteins $2 B$ and 3 inhibits dengue virus replication. Biochem Biophys Res Commun 2013; 440: 393-8.

24 Yildiz M, Ghosh S, Bell JA, Sherman W, Hardy JA. Allosteric inhibition of the NS2B-NS3 protease from dengue virus. ACS Chem Biol 2013; 8: 2744-52.

25 Liu HL, Wu RM, Sun YY, Ye Y, Chen J, Luo XM, et al. Identification of novel thiadiazoloacrylamide analogues as inhibitors of dengue-2 virus NS2B/NS3 protease. Bioorg Med Chem 2014; 22: 6344-52.

26 Tomlinson SM, Malmstrom RD, Russo A, Mueller N, Pang YP, Watowich SJ. Structure-based discovery of dengue virus protease inhibitors. Antiviral Res 2009; 82: 110-4.

27 Deng J, Li N, Liu H, Zuo Z, Liew OW, Xu W, et al. Discovery of novel small molecule inhibitors of dengue viral NS2B-NS3 protease using 
virtual screening and scaffold hopping. J Med Chem 2012; 55: 6278-93.

28 Boonyasuppayakorn S, Reichert ED, Manzano M, Nagarajan K, Padmanabhan R. Amodiaquine, an antimalarial drug, inhibits dengue virus type 2 replication and infectivity. Antiviral Res 2014; 106: 12534.

29 Froehner Junior I, Kotze PG, Rocha JG, Miranda EF, Sartor MC, Martins $\mathrm{JF}$, et al. Postoperative topical analgesia of hemorrhoidectomy with policresulen and cinchocaine: a prospective and controlled study. Revista do Colegio Brasileiro de Cirurgioes 2014; 41: 92-8.

30 Li J, Lim SP, Beer D, Patel V, Wen DY, Tumanut C, et al. Functional profiling of recombinant NS3 proteases from all four serotypes of dengue virus using tetrapeptide and octapeptide substrate libraries. J Biol Chem 2005; 280: 28766-74.

31 Leung D, Schroder K, White H, Fang NX, Stoermer MJ, Abbenante G, et al. Activity of recombinant dengue 2 virus NS3 protease in the presence of a truncated NS2B co-factor, small peptide substrates, and inhibitors. J Biol Chem 2001; 276: 45762-71.

32 Phuong DT, Mai C, Hattori M, Jin JS. Inhibitory effects of antrodins A-E from Antrodia cinnamomea and their metabolites on hepatitis $C$ virus protease. Phytother Res 2009; 23: 582-4.

33 Kim E, Jeon IS, Kim JW, Kim J, Jung HS, Lee SJ. An MTT-based method for quantification of periodontal ligament cell viability. Oral Dis 2007; 13: 495-9.

34 Hamilton MA, Russo RC, Thurston RV. Trimmed Spearman-Karber method for estimating median lethal concentrations in toxicity bioassays. Environment Sci Technol 1977; 11: 714-9.

35 Friesner RA, Banks JL, Murphy RB, Halgren TA, Klicic JJ, Mainz DT, et al. Glide: a new approach for rapid, accurate docking and scoring. 1. Method and assessment of docking accuracy. J Med Chem 2004; 47: 1739-49.

36 Halgren TA, Murphy RB, Friesner RA, Beard HS, Frye LL, Pollard WT, et al. Glide: a new approach for rapid, accurate docking and scoring. 2. Enrichment factors in database screening. J Med Chem 2004; 47: 1750-9.

37 Friesner RA, Murphy RB, Repasky MP, Frye LL, Greenwood JR, Halgren $\mathrm{TA}$, et al. Extra precision glide: docking and scoring incorporating a model of hydrophobic enclosure for protein-ligand complexes. J Med Chem 2006; 49: 6177-96.

38 Shelley JC, Cholleti A, Frye LL, Greenwood JR, Timlin MR, Uchimaya M. Epik: a software program for $\mathrm{pK}(\mathrm{a})$ prediction and protonation state generation for drug-like molecules. J Computer-Aided Mol Design 2007; 21: 681-91.

39 Greenwood JR, Calkins D, Sullivan AP, Shelley JC. Towards the comprehensive, rapid, and accurate prediction of the favorable tautomeric states of drug-like molecules in aqueous solution. J Computer-Aided Mol Design 2010; 24: 591-604.

40 Carrigan PE, Ballar P, Tuzmen S. Site-directed mutagenesis. Methods Mol Biol 2011; 700: 107-24.

41 An M, Chang Z, Gao L, Li M, Cao GF. Determination of four related substances in policresulen solution by HPLC. Chin J Pharm Analysis 2004; 24: 535-7.

42 Zou G, Xu HY, Qing M, Wang QY, Shi PY. Development and characterization of a stable luciferase dengue virus for highthroughput screening. Antiviral Res 2011; 91: 11-9.

43 Celej MS, Montich GG, Fidelio GD. Protein stability induced by ligand binding correlates with changes in protein flexibility. Protein science: a publication of the Protein Society 2003; 12: 1496-506.

44 Amaraneni SR, Kumar S, Gourinath S. Biophysical aspects of lysozyme adduct with monocrotophos. Anal Bioanal Chem 2014; 406: 5477 -
85

45 Peng G, Liu BL, Zhao CX, Jiang ZW. ph-induced conformational transitions of bovine serum albumin investigated by ultraviolet derivative spectroscopy. J Graduate School Chin Acad Sci 2011; 28: 12-7.

46 Chen T, Zhu S, Cao H, Shang Y, Wang M, Jiang G, et al. Studies on the interaction of salvianolic acid $B$ with human hemoglobin by multispectroscopic techniques. Spectrochim Acta A Mol Biomol Spectrosc 2011; 78: 1295-301.

47 Sahoo BK, Ghosh KS, Dasgupta S. Molecular interactions of isoxazolcurcumin with human serum albumin: spectroscopic and molecular modeling studies. Biopolymers 2009; 91: 108-19.

$48 \mathrm{GmbH}$ BA. 1-Hydroxy-4-methylpolyphenylmethansulfonsauren. Germany patent 2245411. 1974 Mar 21.

49 Coulerie P, Maciuk A, Eydoux C, Hnawia E, Lebouvier N, Figadere B, et al. New inhibitors of the DENV-NS5 RdRp from Carpolepis laurifolia as potential antiviral drugs for Dengue treatment. Rec Nat Prod 2014; 8: 286-9.

50 Xie X, Wang QY, Xu HY, Qing M, Kramer L, Yuan Z, et al. Inhibition of dengue virus by targeting viral NS4B protein. J Virol 2011; 85: 11183-95.

51 Rothan HA, Abdulrahman AY, Sasikumer PG, Othman S, Rahman NA, Yusof R. Protegrin-1 inhibits dengue NS2B-NS3 serine protease and viral replication in MK2 cells. J Biomed Biotechnol 2012; 2012: 251482

52 Phong WY, Moreland NJ, Lim SP, Wen DY, Paradkar PN, Vasudevan SG. Dengue protease activity: the structural integrity and interaction of NS2B with NS3 protease and its potential as a drug target. Biosci Reports 2011; 31: 399-409.

53 Tyndall JD, Fairlie DP. Macrocycles mimic the extended peptide conformation recognized by aspartic, serine, cysteine and metallo proteases. Curr Med Chem 2001; 8: 893-907.

54 Faucher AM, Bailey MD, Beaulieu PL, Brochu C, Duceppe JS, Ferland JM, et al. Synthesis of BILN 2061, an HCV NS3 protease inhibitor with proven antiviral effect in humans. Org Lett 2004; 6: 2901-4.

55 Liverton NJ, Carroll SS, Dimuzio J, Fandozzi C, Graham DJ, Hazuda D, et al. MK-7009, a potent and selective inhibitor of hepatitis $C$ virus NS3/4A protease. Antimicrob Agents Chemother 2010; 54: 305-11.

56 Harper S, McCauley JA, Rudd MT, Ferrara M, DiFilippo M, Crescenzi B, et al. Discovery of MK-5172, a macrocyclic hepatitis C virus NS3/4A protease inhibitor. ACS Med Chem Lett 2012; 3: 332-6.

57 Chanprapaph S, Saparpakorn P, Sangma C, Niyomrattanakit P, Hannongbua S, Angsuthanasombat $\mathrm{C}$, et al. Competitive inhibition of the dengue virus NS3 serine protease by synthetic peptides representing polyprotein cleavage sites. Biochem Biophys Res Commun 2005; 330: 1237-46.

58 Ganesh VK, Muller N, Judge K, Luan CH, Padmanabhan R, Murthy KH. Identification and characterization of nonsubstrate based inhibitors of the essential dengue and West Nile virus proteases. Bioorg Med Chem 2005; 13: 257-64.

59 Mueller NH, Pattabiraman N, Ansarah-Sobrinho C, Viswanathan P, Pierson TC, Padmanabhan R. Identification and biochemical characterization of small-molecule inhibitors of west nile virus serine protease by a high-throughput screen. Antimicrob Agents Chemother 2008; 52: 3385-93.

60 Guo ZR. The application of old drugs to molecular design. Chin J Med Chem 2010; 20: 217-25.

61 Noble CG, Seh CC, Chao AT, Shi PY. Ligand-bound structures of the dengue virus protease reveal the active conformation. J Virol 2012; 86: $438-46$. 